\title{
Functional properties of unmodified and modified Jack bean (Canavalia ensiformis) starches
}

\author{
*Yusuf, A. A. ${ }^{{ }^{*}}$ Ayedun, H. $^{2}$ and Logunleko, G. B ${ }^{3}$ \\ ${ }^{1}$. Department of Chemistry, University of Agriculture, Abeokuta, Ogun state, Nigeria \\ 2. Department of Science Laboratory Technology,Federal Polytechnic, Ilaro, Ogun State, Nigeria \\ ${ }^{3 .}$ Department of Chemistry, Tai Solarin University of Education, Ijebu Ode, Ogun state, Nigeria. \\ *Address for Correspondence, E-mail yusufaa2000@yahoo.com
}

\begin{abstract}
The native Jack bean (Canavalia eniformis) starch was chemically modified through oxidation and acetylation. Proximate composition analysis revealed higher moisture, protein, fat and ash contents "native unmodified than modified starches and higher yield in modified starches. Swelling capacity and solubility of all the starches increased with increasing temperature and $\mathrm{pH}$ (up to their optimum point); Oil absorption capacity of modified

starches are found to be higher than unmodified starches, but reversed is the case for water absorption capacity. Gel forming capacity indicates the highest LGC for oxidized and lowest LGC for unmodified starches. Acetylated starch was found to have highest alkaline water retention capacity than others starches studied.

Key words: Functional properties, jack bean, starch, acetylation, oxidation
\end{abstract}

\section{INTRODUCTION}

Ctarch is a carbohydrate polymer made up of an hydroglucose units linked primarily though alpha1, 4 glucosidic bonds. Diversity stems from a starch's mixture of two types of polymers- amylose and amylopectin. The different characteristics of these molecules play a central role in the versatility of starch in foods. Physical and chemical modifications lead to other differences, which expand the uses of starch. (Carooca, et al. 1996).

Starches can be physically modified in a number of ways, including different drying techniques, to provide pearl starches and pregelatinized starches, re-dried starches, agglomerated starches or coldwater-swelling starches. Cold-water-swelling starches, also known as granular starches, have been physically modified to retain granular integrity in a pregelatinised starch (Ronald, 2002). They are not 
information about its physico-chemical properties of its native starch, oxidized starch and acetylated starch. It is the objective of this study therefore, to provide information on the proximate composition, effect of temperature and $\mathrm{pH}$ on solubility and swelling properties of jack bean starches.

\section{MATERIALS AND METHODS}

\section{Collation of sample and isolation of starch.}

Jack bean was obtained at Abeokuta, Nigeria.The seeds were dehulled, sun-dried (30 \pm $2^{\circ} \mathrm{C}$ ) and ground to pass through a 60 -mesh sieve (British standard) to obtain fine powder. The starch was isolated from the sample fine powder using the method of Sathe and Salunkhe, (1981)

\section{Acetylation and Oxidation of Starch.}

Twenty percent starch slurries (w/v) in distilled water were used for both acetylation and oxidation by following the description of Sathe and Salunkhe, (1981).

\section{Proximate composition}

Standard methods of the Association of Official Analytical Chemists (AOAC, 1984) were used for moisture, nitrogen (protein was 6.25\%) fat, and ash determinations.

\section{Water and Oil Absorption Capacities}

The water and oil absorption characteristics of the unmodified and modified starches were determined as described by Oshodi and Ekperign (1989).

\section{Solubility and Swelling}

The solubility swellings of the unmodified and modified starches were determined using Sathe and Salunkhe (1981) method. Effect of pH on solubility and swelling of starches was carried out by preparing $1 \%(\mathrm{w} / \mathrm{v})$ slurry in distilled water and $\mathrm{pH}$ adjusted to the desired value with $0.1 \mathrm{M} \mathrm{HCl}$ or $0.1 \mathrm{M}$ $\mathrm{NaOH}$. The slurries were allowed to stand at room temperature for $30 \mathrm{~min}$, centrifuged $(2,500 \mathrm{rpm})$ and the solubility (\%) and swelling (\%) were determined. Effect of temperature on solubility and swelling of starch was similarly studied by preparing $1 \%(\mathrm{w} / \mathrm{v})$ starch slurry in distilled water for $30 \mathrm{~min}$ at the desired temperature $\left(60,70,80\right.$ and $\left.90^{\circ} \mathrm{C}\right)$.

Alkaline water retention capacity.

Jack bean and wheat flour was blended to give $10,20,30,40$, and $50 \%$ purified starch. $1 \mathrm{~g}$ of each blend were introduced into a test-tube; $5 \mathrm{ml}$ of O. $1 \mathrm{MNaHCO}_{3}$ was added and mixed for $30 \mathrm{sec}$ in a vari-whirl mixer. The samples were allowed to stand for $25 \mathrm{~min}$ at room temperature, centrifuged at $2,000 \mathrm{rpm}$ for $15 \mathrm{~min}$. and drained for $10 \mathrm{~min}$. The test tubes with their contents were weighed and the alkaline water retention was calculated.

\section{Gelation}

The least gelation concentrations of the unmodified and modified Jack bean starches were determined according to the methods of Coffman and Garcia (1977)

\section{RESULTS AND DISCUSSION}

The chemical composition of unmodified, oxidizes and acetylated Jack bean starches are shown in Table 1. Table 2 shows that modification of Jack bean starch reduces water absorption capacity. Gelation properties of native and modified jack bean starches are shown in Table 3. Effect of modification on the gelation of Jack bean starches was given in Table.4. . Effect of temperature on solubility, $\mathrm{pH}$ on solubility, temperature on swelling, and $\mathrm{pHon}$ swelling of Jack bean starches are shown in Figs. 1,2,3 and 4 respectively.

Unmodified Jack bean starches have more moisture, protein, fat and ash contents than modified starches. However, acetylating and oxidation reaction does not induce important changes in the derivatives composition produced according to the treatments obtained compared with the native starch (Table 1). Acetylated Jack bean starch had higher water absorption capacity than oxidized starch. Oxidized and acetylated Jack bean starches had the higher oil absorption (4.51, $4.19 \%$ respectively) than native starch $(3.8 \%)$. This shows that oxidation and 
acetylating can be used to improve oil absorption capacity of jack bean starch.

Acetylating and oxidation increased the solubility (Fig. 1) and swelling power of the granules (Fig.3). The highest solubility and swelling capacity in all cases were observed at $90^{\circ} \mathrm{C}$. This shows that penetrating power of water into the granules of the starches studies can be increased at high temperature. This trend has been observed for Canavalia ensiformis by Ancona, et al (1997) and bambara groundnut by Lawal et al (2004).

The highest solubility and swelling capacities of acetylated sample starch may be due to the introduction of hydrophilic substituting groups that allow the retention of water molecules because of their ability to form hydrogen bonds. This ensures high retention of water that enters the granule, increasing the swelling capacity. This is a useful property in the manufacture of some confectionary products. The effect of $\mathrm{pH}$ on solubility and swelling capacity of Jack bean starches is presented in Fig. 2 and 4 respectively. In both cases, modified starches recorded higher solubility and swelling capacity at various $\mathrm{pH}$. Maximum solubility was obtained at

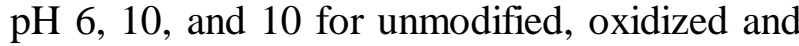
acetylated starches respectively. While that of swelling capacity are at $\mathrm{pH} 8,8$ and 10 for unmodified, oxidized and acetylated starches respectively.

Figs. 1, 2, 3 and 4 however, show that maximum solubility and swelling capacity could be obtained at $90^{\circ} \mathrm{C}$ and $\mathrm{pH}$ 6-8 for unmodified; $90^{\circ} \mathrm{C}$ and $\mathrm{pH}$ 810 for oxidized; and $90^{\circ} \mathrm{C}$ and $\mathrm{pH} 10$ for acetylated jack bean starches.

Using the least gelation concentration (LGC) as an index of gelation, the result obtained in this study indicates the highest LGC for oxidized starch and lowest LGC for unmodified starch. In all the samples studied, increasing concentration facilitated gelation properties. This may be due to the enhancement of interaction occurred among the binding forces as the concentration increased. The introduction of carbonyl and carboxyl groups probably caused intermolecular repulsions that limited interaction of oxidized starch molecules, which led to reduction in gelation properties. (Lawal, et.al, 2004).

Considering the values of alkaline water retention capacity of unmodified and modified starches (Table 4) shows that acetylated starch have highest alkaline water retention capacity. This may be due the fact that the protein components of wheat flour cannot realize their full potentials in the presence of acetyl group. 


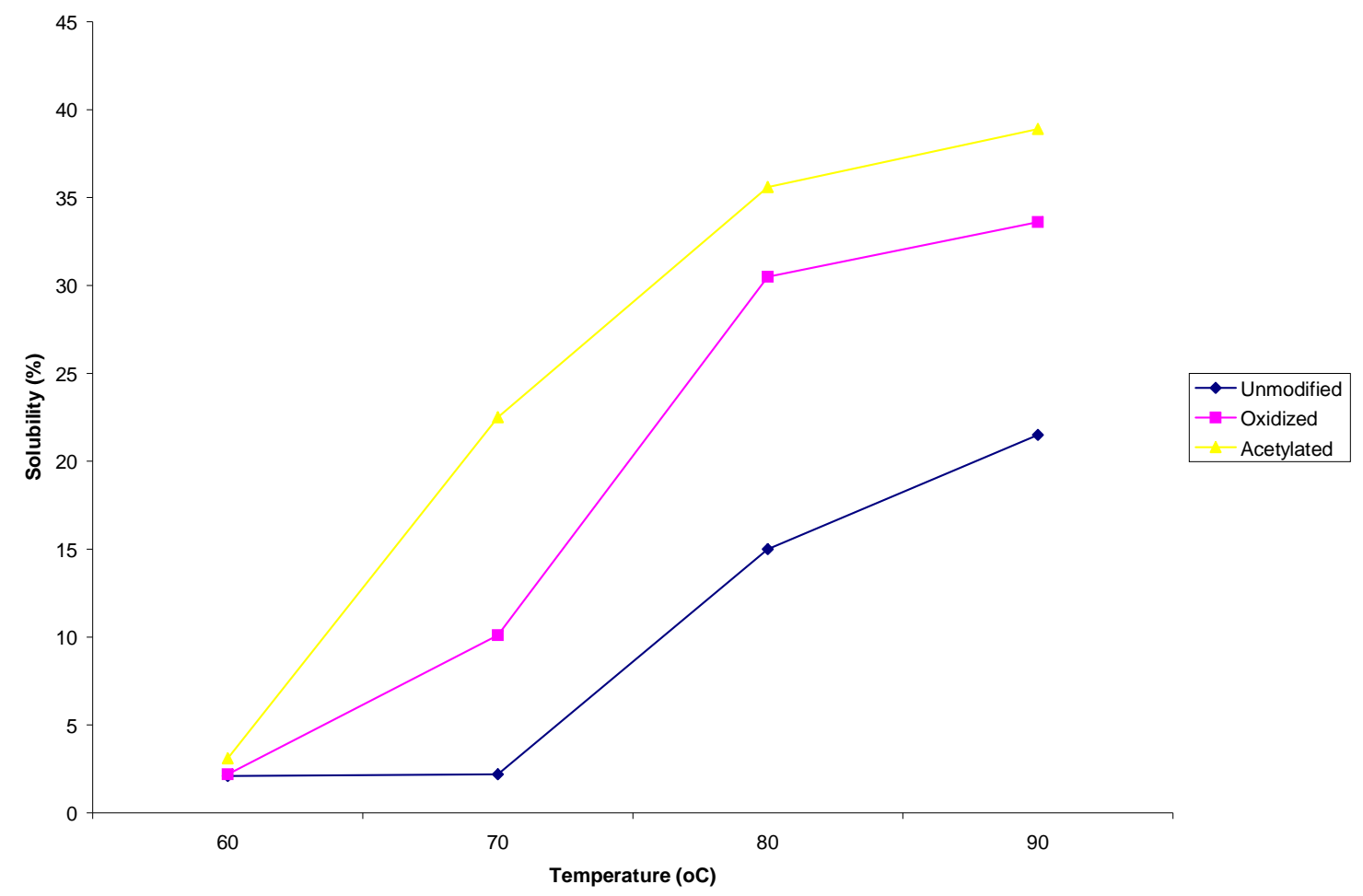

Fig 1. Effect of temperature on solubility of Jack bean starches. 


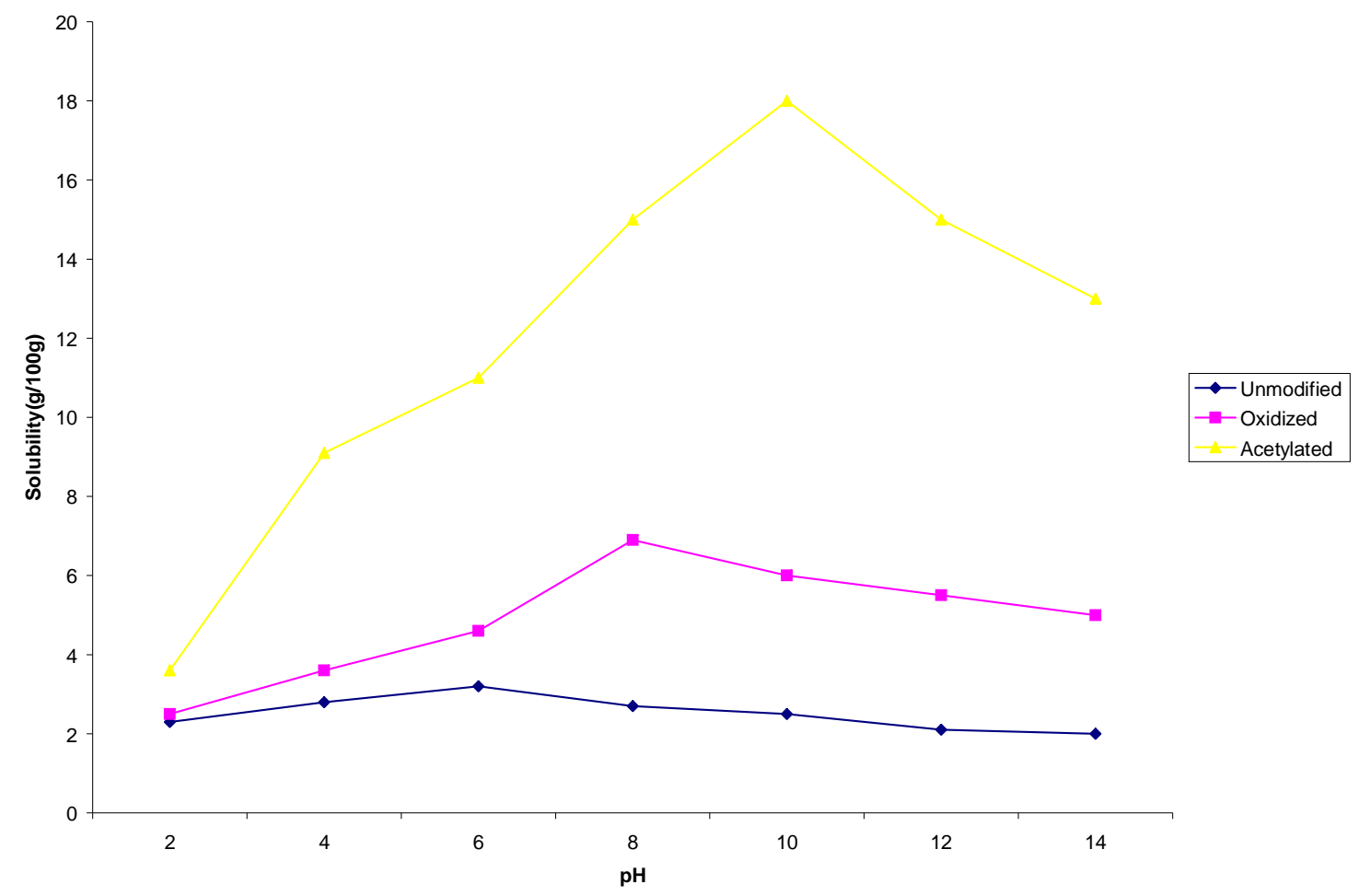

Fig 2. Effect of pH on solubility of Jack bean starches 


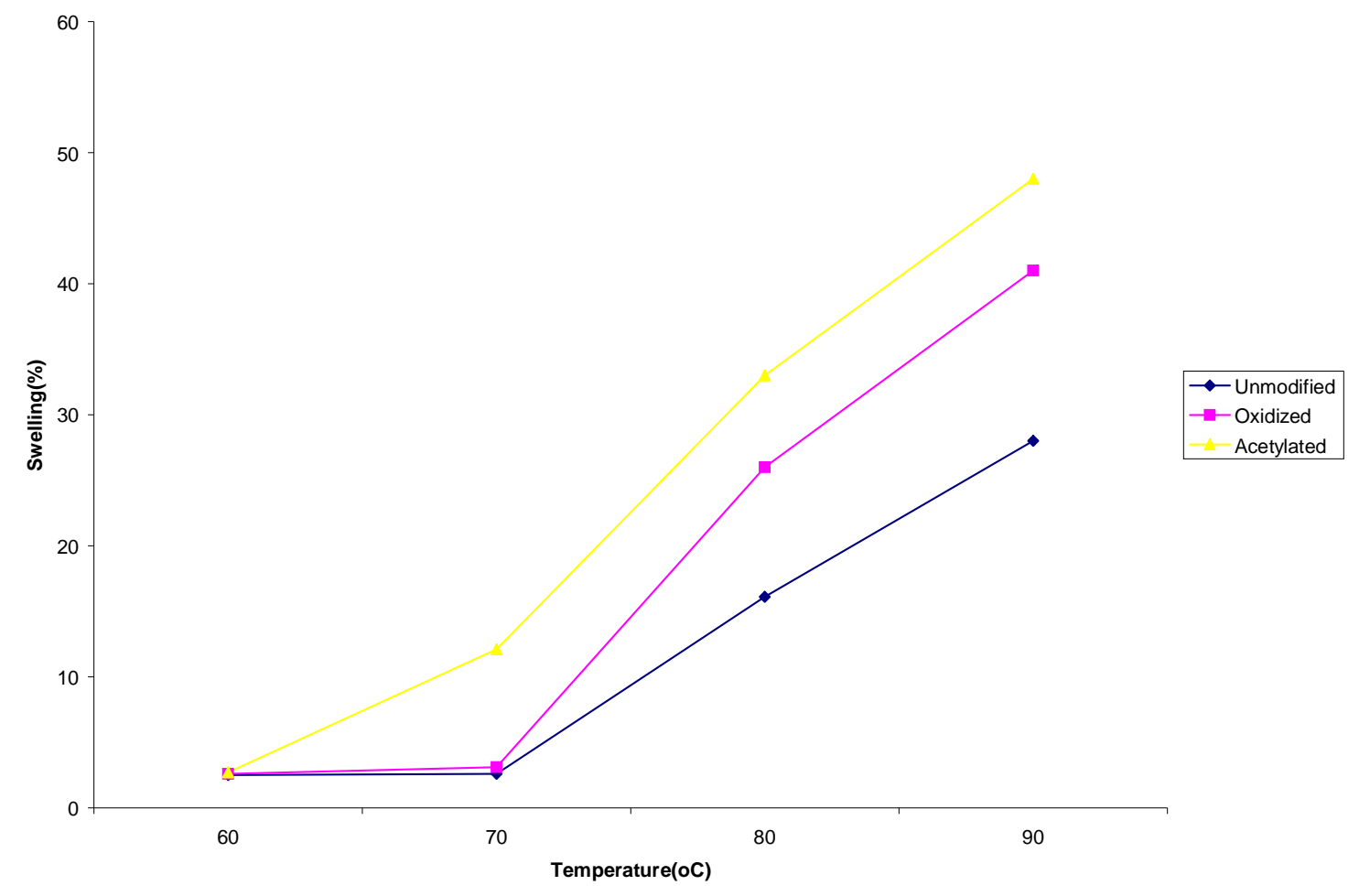

Fig 3.Effect of temperature on swelling of Jack bean starches 


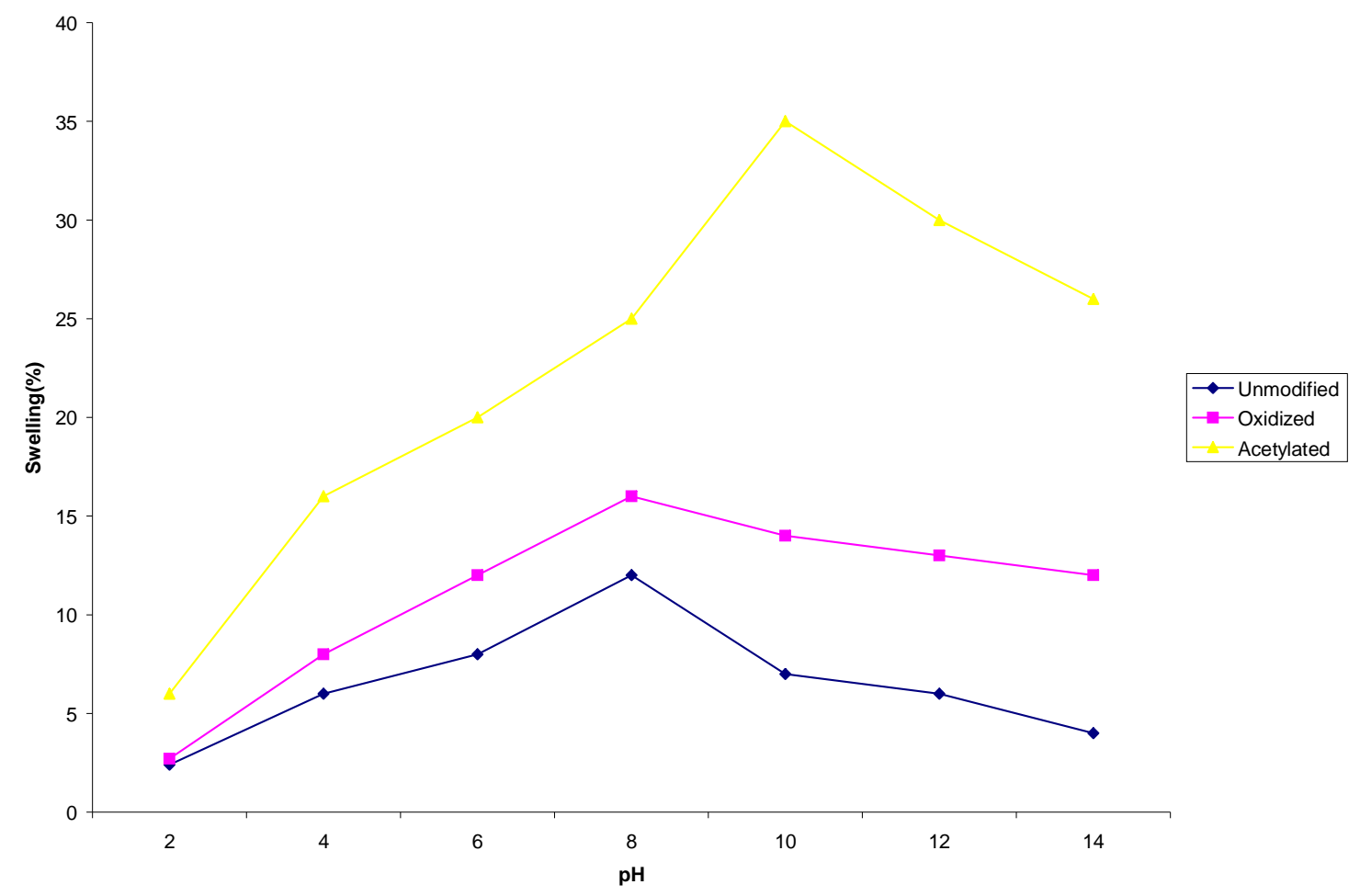

Fig 4. Effect of pH on swelling of Jack bean starches 
Functional properties of unmodified and modified jack bean starches......

Table 1. Proximate composition of Jack bean starches.

\begin{tabular}{lccc}
\hline Parameter (\%) & Unmodified & Oxidized & Acetylated \\
\hline Yield & $37.20 \pm 1.12$ & $87.34 \pm 2.01$ & $81.28 \pm 2.31$ \\
Moisture & $10.31 \pm 0.34$ & $2.89 \pm 0.10$ & $4.50 \pm 0.51$ \\
Protein & $0.92 \pm 0.06$ & $0.47 \pm 0.08$ & $0.73 \pm 0.05$ \\
Fat & $0.36 \pm 0.01$ & - & - \\
Ash & $0.10 \pm 0.01$ & - & - \\
\hline
\end{tabular}

All values are shown as means $\pm S D$

Table 2. Water and oil absorption capacities of Jack bean starches

\begin{tabular}{lccc}
\hline & Unmodified & Oxidized & Acetylated \\
\hline Water absorption capacity (\%) & $3.11 \pm 0.22$ & $1.75 \pm 0.11$ & $2.81 \pm 0.01$ \\
Oil absorption capacity (\%) & $3.80 \pm 0.31$ & $4.51 \pm 0.21$ & $4.19 \pm 0.32$ \\
\hline
\end{tabular}

All values are shown as means $\pm S D$

Table 3. Alkaline water retention capacity (AWRC) of unmodified, oxidized and acetylated Jack bean starches.

\begin{tabular}{|c|c|c|c|c|}
\hline \multicolumn{2}{|c|}{ Starch and Wheat flour blend } & \multicolumn{3}{|l|}{$\operatorname{AWRC}(g / g)$} \\
\hline $\operatorname{Starch}(\%)$ & Wheat flour $(\%)$ & Unmodified & Oxidized & Acetylated \\
\hline 100 & 0 & $2.26 \pm 0.01$ & $2.32 \pm 0.02$ & $3.51 \pm 0.03$ \\
\hline 90 & 10 & $1.91 \pm 0.02$ & $2.26 \pm 0.01$ & $3.22 \pm 0.01$ \\
\hline 80 & 20 & $1.64 \pm 0.01$ & $2.10 \pm 0.02$ & $2.74 \pm 0.04$ \\
\hline 70 & 30 & $1.46 \pm 0.01$ & $2.37 \pm 0.03$ & $2.15 \pm 0.02$ \\
\hline 60 & 40 & $1.40 \pm 0.03$ & $1.96 \pm 0.01$ & $2.04 \pm 0.01$ \\
\hline 50 & 50 & $1.30 \pm 0.02$ & $1.86 \pm 0.03$ & $1.96 \pm 0.01$ \\
\hline
\end{tabular}

All values are shown as means $\pm S D$ 
Table 4.Effect of modification on the gelation of Jack bean starches.

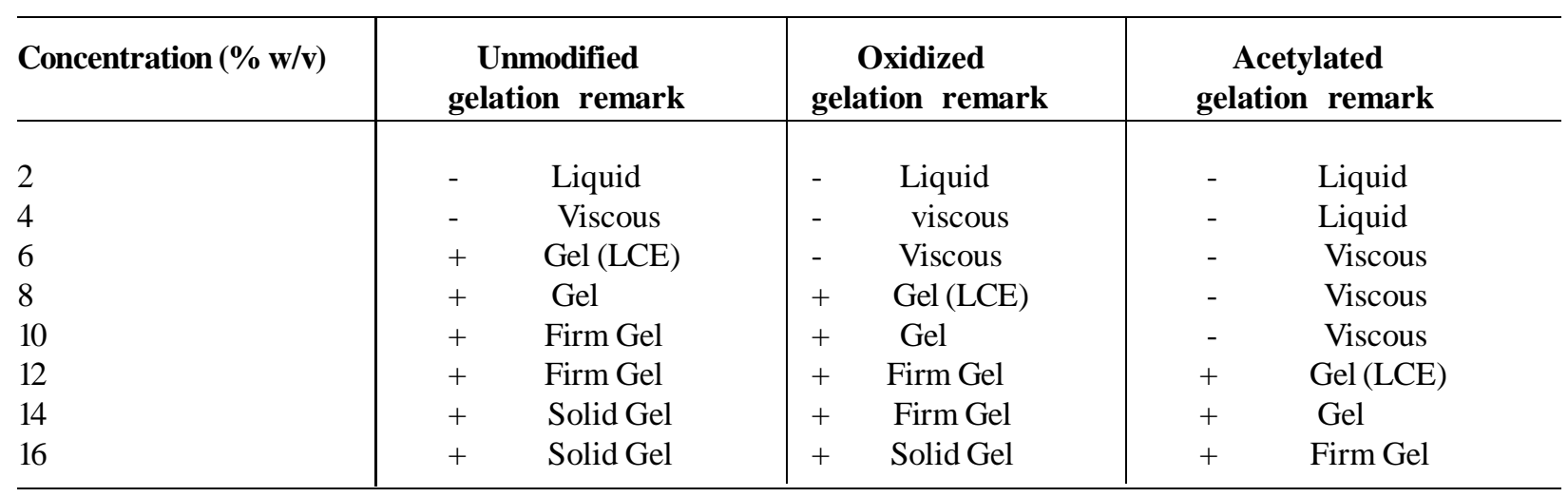

$(-)=$ no gelation,$(+)=$ gelation, and $L C E=$ Least concentration endpoint, which is the lowest starch concentration at which gel remained in the inverted tube.

\section{REFERENCES}

Ancana D. B., Guerrero L., and Hernandez . (1997). Acetylation and Characterization of Canavalia ensiformis starch, J. Agric. Food Chem. 45: $375-382$.

Bamiro, F.O., Tairu, A.O. and Oderinde, R.A. (1994). The Nutritive values of Nigerian Jack beans (Canavalin ensiformis) La Rivista Heliana Delle Sastance citrasse Vol. LXXI; $421-424$.

Carioca, J.O.B; Arora, H.L; Pannir, P.V; Selvan Tavares, F.C.A; Kennedy, J.F. and Knill, C.J. (1996). Industrial Utilisation of starch and its Derived Product in Brazil. Starch/starke 48 (9): 121 - 130.

Coffman, C. W. and Grarcia, V. V. (1977). Functional properties and Amino acid Content of protein isolate from mug bean flour. J. Food Tech. 12: $473-484$.

Kunkpetoon D. Wang. Y.J. (2001). Characterization of different starches oxidized by hypochlorite. Starch 53: $211-218$.
Lawal, O.S. Adebowale, K.O. and Oderinde, R.A. (2004). Functional properties of amylopectin and amplose fractions isolated frombambarra Groundnut (Voandzeia Subterranean) starch; African Journal of Bioctechnology 318): $399-404$.

Oshodi, A. A. and Ekperigin, M. M. (1989). Functional properties of pigeon coacentrates. Food. Chem. 34: 187 - 191.

Ronrald, C.D. (2002). Multifunctionality for Modified starches. Weeks Publishing Co. U.S.A. (www.foodproduct design.com).

Sathe, S.K. and Salunkhe, D.K. (1981). Functional properties of the great Norther bean (Phasoelus vulgraris L.) Protein emulsion, foaming, viscosity and gelation properties J. Food Sci. 46: 71 - 74 